\title{
Anthrax Toxin Receptor 1
}

National Cancer Institute

\section{Source}

National Cancer Institute. Anthrax Toxin Receptor 1. NCI Thesaurus. Code C104095.

Anthrax toxin receptor 1 (564 aa, $\sim 63 \mathrm{kDa}$ ) is encoded by the human ANTXR1 gene. This

protein plays a role in the regulation of both cell adhesion and cellular motility. 